\title{
HUBUNGAN PERSEPSI SISWA TENTANG METODE PEMBELAJARAN TEAM TEACHING TERHADAP MOTIVASI PENYELESAIN TUGAS GAMBAR TEKNIK
}

\author{
Amin Solihin', Ono Wiharna ${ }^{2}$, Mumu Komaro ${ }^{3}$ \\ Departemen Pendidikan Teknik Mesin \\ Universitas Pendidikan Indonesia \\ Jl. Dr. Setiabudhi No. 207 Bandung 40154 \\ amin.solihin@student.upi.edu
}

\begin{abstract}
ABSTRAK
Penelitian ini bertujuan untuk mengetahui memperoleh gambaran persepsi siswa tentang pelaksanaan metode pembelajaran team teaching, motivasi siswa dalam penyelesaian tugas gambarnya dan dan hubungan persepsi siswa tentang metode pembelajaran team teaching terhadap motivasi siswa dalam penyelesaian tugas gambar. Pengambilan data menggunakan angket. Populasi dalam penelitian ini adalah seluruh siswa kelas X Jurusan Teknik Kendaraan Ringan SMK Negeri 8 Bandung sebanyak 230 siswa dan jumlah sampel sebanyak 58 responden. Hasil penelitian diperoleh persamaan regresi $\mathrm{Y}=36.33+0,27 \mathrm{X}$, dengan koefisien determinasi menunjukkan persentase sebesar 7,3\%. Kesimpulan dari penelitian ini adalah persepsi siswa tentang metode pembelajaran team teaching dalam kategori baik. Motivasi penyelesaian tugas gambar cenderung dalam kategori yang cukup tinggi. Ada hubungan yang positif dan signifikan antara persepsi siswa tentang metode pembelajaran team teaching terhadap motivasi penyelesain tugas gambar pada mata pelajaran gambar teknik. Persepsi siswa tentang metode pembelajaran team teaching akan mempengaruhi motivasi penyelesain tugas gambar pada mata pelajaran gambar teknik.
\end{abstract}

Kata kunci: team teaching, motivasi, persepsi, gambar teknik.

\section{PENDAHULUAN}

Pendidikan merupakan salah satu komponen penting dalam meningkatkan kualitas sumber daya manusia. Upaya meningkatkan sumber daya manusia yang berkualitas dan siap kerja, perlu adanya peningkatan kualitas pendidikan khususnya pada jenjang sekolah menengah kejuruan (SMK). Karena SMK ini bertujuan untuk mempersiapkan peserta didik yang mempunyai keterampilan tertentu untuk memasuki dunia kerja. Berkembangnya dunia pendidikan pada saat ini merupakan tantangan untuk mengembangkan kemampuan dalam dunia pendidikan. Undang-undang Nomor 20 Tahun 2003 tentang Sistem Pendidikan Nasional (UUSPN), pasal 3 menyatakan bahwa: pendidikan nasional berfungsi mengembangkan kemampuan serta membentuk watak dan peradaban bangsa yang bermartabat dalam rangka mencerdaskan kehidupan bangsa, bertujuan untuk mengembangkan potensi peserta didik agar menjadi manusia yang beriman dan bertakwa kepada Tuhan Yang Maha Esa, berakhlak mulia, sehat, berilmu, cakap, kreatif, mandiri, dan menjadi warga negara yang demokratis serta bertanggung jawab.

\footnotetext{
${ }^{1}$ Mahasiswa Departemen Pendidikan Teknik Mesin FPTK UPI

${ }^{2}$ Dosen Departemen Pendidikan Teknik Mesin FPTK UPI

${ }^{3}$ Dosen Departemen Pendidikan Teknik Mesin FPTK UPI
} 
Usaha mencapai tujuan pendidikan nasional yang antara lain yaitu meningkatkan ketakwaan kepada Tuhan Yang Maha Esa, kecerdasan dan keterampilan maka salah satu usaha yang ditingkatkan adalah menumbuhkan kemandirian belajar pada siswa diberbagai sekolah, dengan menumbuhkan minat dan motivasi belajar yang baik maka pembelajaran akan berlangsung dengan baik (Sadirman, 2014). Sekolah Menengah Kejuruan (SMK) yang merupakan suatu lembaga pendidikan formal dimana lulusannya dipersiapkan untuk memasuki dunia kerja dan memiliki kemampuan yang sesuai dengan kebutuhan industri.Sekolah bukan saja mengharapkan siswa yang mampu, cakap, dan terampil, tetapi yang terpenting mereka mau giat belajar dan berkeinginan untuk mencapai hasil belajar yang optimal. Kemampuan, kecakapan, dan keterampilan tidak ada artinya jika mereka tidak mau bekerja keras dengan mempergunakan kemampuan, kecakapan, dan keterampilan yang dimilikinya (Rakhmat, 2007).

Sekolah Menengah Kejuruan (SMK) Negeri 8 Bandung mempunyai beberapa program keahlian, diantaranya Teknik Kendaraan Ringan (TKR), Teknik Sepeda Motor (TSM), dan Teknik Perbaikan Body Otomotif (TPBO). Semua program keahlian tersebut memiliki mata pelajaran yaitu gambar teknik untuk menunjang siswa nantinya dalam membaca gambar di industri (Mangkunegara, 2007). Mata pelajaran gambar teknik tak hanya satu semester di awal saja di kelas X, tetapi belanjut sampai kelas XI.

Khususnya pada pelaksanaan pembelajaran gambar teknik, sekolah menyediakan berbagai fasilitas belajar diantaranya: meja gambar, kertas gambar, penggaris dan yang lainnya. Media pendukung informasi seperti: LCD projector sebagai alat bantu guru saat menjelaskan materi pembelajaran dan tentunya fasilitas ruangan kelas beserta atributnya seperti papan tulis beserta alat tulisnya (Mulyana, 2000). Hal ini bertujuan agar dapat mendukung kebutuhan siswa dalam kegiatan pembelajaran yang lebih kondusif, khususnya disaat siswa mengerjakan tugas gambar terstruktur yang merupakan salah satu syarat kelulusan mata pelajaran gambar teknik sebagai bekal mendasar dalam membaca gambar untuk masuk ke dunia industri.

Selain aspek sarana yang dijadikan bahan pendukung kegiatan pembelajaran, aspek prasarana seperti metode pembelajaran guru pun digunakan agar guru mengajar lebih sistematis dan proses pembelajaran untuk siswa lebih terarah selama kegiatan pembelajaran. Terutama mengontrol dan membimbing saat siswa mengerjakan tugas gambar terstruktur di kelas. Siswa dapat berkonsultasi tentang masalah pada tugasnya misalnya dari segi teknik ataupun bertanya mengenai aturan gambar yang tidak dimengerti (Wirawan, 2002). Setiap pertemuan siswa diwajibkan untuk melaporkan progres dari 
pengerjaan tugasnya kepada guru. Seiring dengan banyaknya tugas gambar yang harus diselesaikan, dalam satu semester tugas gambar terdapat kurang lebih 12 tugas gambar, siswa merasa bosan dan tidak bersemangat, sehingga muncul beberapa masalah. Beberapa siswa masih terlihat tidak terlalu peduli terhadap penyelesaian tugas gambarnya. Seperti anak yang membolos atau adanya siswa yang masih menyuruh temannya untuk mengerjakan tugasnya. Hal ini akan menghambat siswa itu sendiri dalam penyelesaian tugas gambarnya.

Siswa tidak berani memberi komentar mengenai pelaksanaan pembelajaran team teaching secara langsung. Alasan siswa tidak memberikan komentar pada guru yang mengajar dikarenakan ada rasa segan atau sebagian murid merasa takut dan kurang sopan bila langsung memberikan komentar terhadap guru yang bersangkutan. Beberapa siswa merasa kurang nyaman dengan sikap guru dalam mengembangkan sikap positif pada diri siswa. Contohnya terjadi pada saat mengoreksi tugas yang dikumpulkan siswa, guru mengoreksi dan memberikan saran untuk membenarkan lagi tugas gambarnya. Hal ini menyebabkan adanya anggapan dari siswa yang berlebih sehingga mempersepsikan bahwa itu bukanlah motivasi.

Aspek metode pembelajaran team teaching dan motivasi siswa dalam penyelesaian tugas gambar. Kedua aspek tersebut berada dalam ruang lingkup pelajaran gambar teknik. Walaupun berbeda aspek, namun masih dalam satu ruang lingkup yang memiliki keterkaitan antar satu dengan yang lainnya (Roestiyah, 2001). Berdasar pada fenomena permasalahan di atas, perlu dilakukan penelitian untuk mengetahui hubungan antara metode pembelajaran team teaching dengan motivasi penyelesaian tugas gambar. Kedua aspek tersebut merupakan objek sementara siswa sebagai subjek. Upaya dalam mengetahui aspek-aspek tersebut, salah satu caranya ialah dengan usaha mendapatkan jawaban pernyataan dari siswa mengenai persepsinya terhadap metode pembelajaran team teaching dan penyataan siswa dalam motivasi penyelesaian tugas gambarnya. Sehingga dari aspek tersebut, bisa diteliti mengenai hubungan antara keduanya yang masih berada dalam satu lingkup mata pelajaran gambar teknik di SMK Negeri 8 Bandung.

\section{METODE PENELITIAN}

Pada penelitian ini yang digunakan adalah deskriftif kuantitatif, yaitu pendekatan yang menggunakan data yang dikualifikasikan dan menganalisisnya dengan analisis statistik. Pendekatan ini memungkinkan dilakukan pencatatan dan penganalisisan data hasil penelitian dengan menggunakan statistik. Populasi peserta didik kelas X keahlian Teknik 
Kendaraan Ringan SMK Negeri 8 Bandung terdiri dari 230 orang. Sampel sebanyak 58 orang $(25 \%$ x230). Sampel yang diambil dalam penelitian ini merupakan sampel random. Hal ini dilakukan dengan cara mengambil anggota sampel dari populasi yang dilakukan secara acak, untuk penelitian ini peneliti mengambil sampel dari kelas-kelas dengan cara diundi. Instrumen penelitian yang digunakan dalam penelitian ini yaitu angket, wawancara dan dokumentasi. Sebelum angket digunakan, dilakukan uji validitas dan uji reliabilitas serta judgement terhadap isi angket.

\section{HASIL PENELITIAN}

Data yang diperoleh dari instrumen angket adalah data mentah kuantitatif berupa skor jawaban. Data yang diperoleh dari instrumen dokumentasi berupa berkas-berkas, fotofoto, dan rekaman yang mendukung pada penelitian ini. Sebelum dilakukan uji validitas instrumen angket telah dilakukan validitas isi dengan cara judgement. Validitas merujuk pada kesesuaian antara persepsi siswa dengan motivasi penyelesaian tugas. Angket yang sudah valid terdiri dari 25 pernyataan dan dapat digunakan sebagai instrumen penelitian. Uji reliabilitas dilakukan untuk mengukur keajegan suatu alat ukur atau seberapa kuat alat ukur tersebut dapat dipercaya atau dapat diandalkan. Jika skor hasil tes pertama sama dengan skor hasil tes kedua, maka tes dikatakan memiliki reliabilitas yang sangat tinggi. Uji reliabilitas angket ini menggunakan rumus alpha Spearman Borwn. Hasil uji reliabilitas untuk variable $X$ diperoleh $r_{11}=0,70$ dan variable $Y$ diperoleh $r_{11}=0,73$. Sehingga instrumen angket ini dapat dinyatakan memiliki reliabilitas tinggi.

Berdasarkan hasil temuan peneliti bahwa objek yang menjadi bahan persepsi siswa adalah metode pembelajaran team teaching di mana dalam penelitian ini lebih dispesifikasikan dengan batasan penelitian yang hanya segi pelaksanaan metode pebelajaran team teaching selama pengerjaan tugas gambar. Mulai dari proses siswa saat menyimak penjelasan materi, memahami konsep tugas, mendapat bimbingan dan pengawasan dari guru mengenai tugas gambar, menyelesaikan tugas gambar menilai sikap, penampilan guru selama mendampingi siswa mengerjakan tugas gambarnya (Sugihartono, 2007).

Hal tersebut juga berkaitan dengan metode pembelajaran team teaching yang merupakan metode yang dibuat berdasarkan kompetensi guru yang bersangkutan. Hal ini terbukti sejalan dengan penelitian ini, dimana setelah dilakukan penelitian, muncul suatu hasil bahwa persepsi siswa tentang metode pembelajaran team teaching lebih cenderung pada persepsi yang positif (Toha, 2003). 
Berdasarkan hasil perhitungan yang dikemukakan pada gambaran mengenai persepsi siswa tentang metode pembelajaran team teaching pada mata pelajaran gambar teknik di SMK Negeri 8 Bandung cenderung tergolong pada kategori persepsi yang baik. Sehubungan dengan penelitian relevan dia atas, hasil penyebaran angket variabel $\mathrm{X}$ menunjukan bahwa skor rata-rata nya yaitu 3,79. Nilai tersebut menunjukan bahwa persepsi siswa tentang metode pembelajaran team teaching dapat dikategorikan baik . Dari hasil uraian tersebut, dapat dilihat bahwa dari 58 siswa yang menjadi responden terbukti bahwa siswa yang mempunyai persepsi baik terhadap metode team teaching.

\section{PEMBAHASAN}

Setelah dilakukan penelitian, muncul suatu hasil bahwa jawaban dari pernyataan siswa melalui angket variabel Y dengan tujuan untuk mengungkap seberapa besar motivasi siswa dalam penyelesain tugas gambar. Jawaban dari pernyataan siswa yang banyak dikemukakan merupakan jawaban karena siswa menyukai mata pelajaran gambar teknik. Sehingga motivasi siswa muncul dari dalam dirinya, walaupun mata pelajaran tersebut merupakan pelajaran baru bagi mereka yang tidak didapatkan dari sekolah sebelumnya (Shaleh dan Wahab, 2004).

Hasil perhitungan yang dilakukan menunjukan bahwa penyelesaian tugas gambar yang dilakukan oleh siswa mayoritas lebih cenderung pada kategori motivasi yang cukup tinggi. Hal itu terbukti setelah dilakukan langkah uji kecenderungan bahwa nilai rataratanya sebesar 3,93. Hal ini berarti siswa mempunyai motivasi penyelesaian tugas pada kategori baik.

Temuan penelitian menunjukan bahwa variabel X (Persepsi Siswa Tentang Metode Pembelajaran Team Teaching) mempunyai hubungan terhadap variabel Y (Motivasi Penyelesain Tugas Gambar Pada Mata Pelajaran Gambar Teknik). Hal ini dapat dilihat dari perhitungan regresi dan uji korelasi seperti yang menunjukan adanya tingkat keberartian antar variabel $\mathrm{X}$ dan Variabel $\mathrm{Y}$. dilihat dari persamaan regresi $\mathrm{Y}$ atas $\mathrm{X}$ diperoleh harga a sebesar 36,33 dan harga b sebesar 0,27. Setelah diketahui harga a dan b maka didapat persamaan regresi sebesar berikut $\mathrm{Y}=36,33+0,27 \mathrm{X}$. dari persamaan regresi ini dapat diartikan bahwa setiap ada perubahan satu unit pada variabel $\mathrm{X}$ maka akan berpengaruh terhadap perubahan pada variabel $\mathrm{Y}$ sebesar 36,33 dan menandakan bahwa hubungan memiliki arah yang positif dan berpola linier.

Sesuai dengan harga koefesien korelasi dalam penelitian ini menghasilkan hubungan yang positif 0,27 hal ini menunjukan bahwa setiap kenaikan satu satuan pada 
persepsi siswa tentang metode pembelajaran team teaching maka diikuti oleh meningkatnya motivasi siswa dalam penyelesaian tugas gambar. Dengan demikian terdapat hubungan antara persepsi siswa tentang metode pembelajaran team teaching terhadap motivasi penyelesaian tugas gambar testruktur yang saling meningkat. Keberatian tersebut ditunjukan berdasarkan hasil uji t dan uji determinasi. Dari hasil uji t diperoleh angka sebesar 2,11 harga ini dikonsultasikan dengan $\mathrm{t}$ tabel pada $\mathrm{dk}=58-2=56$ pada tingkat kepercayaan 95\% maka harga $\mathrm{t}$ tabel sebesar 1,67. Setelah diketahui harga t hitung dan $\mathrm{t}$ tabel maka dapat disimpulkan bahwa $\mathrm{t}_{\text {hitung }} \geq \mathrm{t}$ tabel yaitu $2,11 \geq 1.67$, ini berarti bahwa persepsi siswa tentang metode pembelajaran team teaching memberikan dampak positif bagi motivasi penyelesain tugas gambar pada mata pelajaran gambar teknik.

Selain itu hipotesis ini diperkuat dengan koefesien determinasi yang menunjukan bahwa 7,30\% terdapat hubungan antara persepsi siswa tentang metode pembelajaran team teaching dengan motivasi penyelesaian tugas gambar. Sedangkan 92,70\% sisanya, termasuk pada aspek-aspek yang tidak tergolong pada aspek penelitian.

\section{KESIMPULAN}

Kesimpulan penelitian ini dapat diambil, sebagai berikut persepsi siswa tentang metode pembelajaran team teaching tergolong pada kategori baik. Metode pembelajaran team teaching pada mata pelajaran gambar teknik ternyata disukai oleh siswa. Motivasi siswa dalam menyelesaikan tugas gambar tergolong memiliki motivasi yang cukup tinggi. Terdapat hubungan yang signifikan antara persepsi siswa tentang metode pembelajaran team teaching terhadap motivasi penyelesain tugas gambar. Persepsi siswa yang baik terhadap metode pembelajaran team teaching dapat meningkatkan motivasi dalam menyelesaiakan tugas gambarnya pada mata pelajaran gambar teknik di SMK Negeri 8 Bandung.

\section{DAFTAR PUSTAKA}

Mulyana, D. (2000). Ilmu Komunikasi Suatu Pengantar. Bandung: PT. Remaja Rosdakarya.

Mangkunegara, AP. (2007). Manajemen Sumber Daya Manusia. Bandung: Remaja Rosdakarya.

Munandar, U. (1992). Mengembangkan Bakat dan Kreativitas Anak Sekolah. Jakarta: Gramedia. 
Rakhmat, J. (2007). Psikologi Komunikasi. Bandung: PT. Remaja Roesdakarya.

Roestiyah. (2001). Team Teaching Sebagai Metode Pembelajaran Modern/ Jakarta: Bumi Aksara.

Sadirman, A. (2014). Motivasi dan Interaksi Belajar Mengajar. Jakarta: PT. Raja Grafindo Persada.

Shaleh dan Wahab. (2004), Psikologi Suatu Pengantar dalam Persepktif Islam. Jakarta: Kencana.

Sugihartono. (2007). Psikologi Pendidikan. Yogyakarta: UNY Press.

Toha, M. (2003). Kepemipinan dalam Manajemen. Jakarta: PT. Raja Grafindo Persada.

Wirawan, S. (2002) . Psikologi Sosial. Jakarta: Balai Pustaka. 